\title{
Adenoma de células basales parotídeo: Revisión a propósito de cuatro casos
}

\author{
Basal cell adenoma of the parotid: A revision based on four cases
}

\author{
M.J. Pastor Fortea ${ }^{1}$, J.I. Iriarte Ortabe², R. Ramos Asensi², M. Morey Mas², J. Caubet Biayna², \\ A. Pozo Porta ${ }^{1}$, I. Forteza-Rey Borralleras ${ }^{3}$
}

Resumen: El adenoma de células basales es un tipo específico de adenoma con una apariencia histológica uniforme y monomorfa, en el que predominan las células basaliodes sin el componente mixocondroide del tumor mixto. Atendiendo a su morfología pueden ser divididos en cuatro subtipos: sólido, tubular, trabecular y membranoso.

Presentamos cuatro casos de adenoma de células basales localizados en glándula parótida: uno de tipo sólido, uno de tipo trabecular y dos de tipo membranoso, tratados mediante parotidectomía superficial conservadora en todos los casos.

Esta división en distintos patrones morfológicos tiene una finalidad descriptiva, salvo en el subtipo membranoso por su mayor tendencia a la multifocalidad y a la recidiva, su ocasional transformación maligna, así como por su posible asociación en un tercio de los casos a tumores ecrinos dermales. Esto implica un seguimiento más estrecho y un despistaje de posibles lesiones cutáneas asociadas.

Palabras clave: Basales; Membranoso; Multifocalidad; Recidiva; Ecrinos.
Abstract: The basal cell adenoma is a specific type of adenoma, with a uniform, monomorphous histologic appearance that is dominated by basaloid cells and that does not have the myxochondroid tissue characteristic of mixed tumors. It may be divided on the basis of its morphologic pattern into four subtypes: solid, tubular, trabecular and membranous. We report four cases of basal cell adenoma subdivided as follows: one solid, one trabecular and two membranous subtypes. In all cases a conservative superficial parotidectomy was the treatment.

Morphologic identification of the specific subtype is for descriptive purposes, except in the case of the membranous type, due to its tendency to be multifocal, its high recurrence rate, its occasional malignant transformation and its possible association in about onethird of the reported cases with dermal cylindromas. A close followup and screening of skin lesions is suggested for these tumors.

Key words: Basal; Membranous; Multifocal; Relapse; Eccrine.

Recibido: 09-05-2004

Aceptado: 21-03-2005

\footnotetext{
1 Médico Residente.

2 Médico Adjunto.

3 Jefe de Servicio

Servicio de Cirugía Oral y Maxilofacial

Hospital Son Dureta, Palma de Mallorca, España.

Correspondencia:

María Jose Pastor Fortea

C/ Illes Balears, $105 \mathrm{~K}$

07015, Palma de Mallorca, España.

email: mjpastor@mundofree.com
} 


\section{Introducción}

El adenoma de células basales (ACB), es una neoplasia epitelial benigna con una apariencia histológica uniforme y monomorfa, en la que predominan las células basaliodes sin el componente mixocondroide del tumor mixto. Representan un $2 \%$ de los tumores primarios de glándulas salivares y se localizan más frecuentemente en la glándula parótida y en las glándulas salivares menores del labio superior. ${ }^{1}$

Ha existido mucha controversia acerca de la terminología y espectro de tumores que pertenecen a ese grupo desde su descripción por Kleinsasser y Klein en 1967.2 En el monográfico acerca de los distintos tipos histológicos de tumores de glándulas salivares, de la Organización Mundial de la Salud (OMS) de 1972,3 había dos categorías de adenoma: pleomorfo y monomorfo. Dentro de los adenomas monomorfos se encontraban el tumor de Warthin, Oncocitoma y Otros tipos, sin una clara definición de estos últimos lo que hizo que distintos patólogos utilizaran el término monomorfo como una entidad diagnóstica. En una revisión más reciente acerca de la clasificación histológica de los tumores de la glándulas salivares de la OMS publicado a finales de 1991, no se utiliza el término monomorfo como categoría diagnóstica y se incluye una variedad de tipos específicos de adenoma, separados por sus distintas características morfológicas, entre los que se encuentra el adenoma de células basales. ${ }^{2,4}$

\section{Casos clínicos}

Presentamos cuatro casos diagnosticados de adenoma de células basales durante los años 2000-2003, de una serie de 92 parotidectomías intervenidas en el Hospital Universitario de Son Dureta durante este periodo de tiempo.

Se trata de 2 hombres y 2 mujeres de entre 17 y 72 años con una medía de edad de 43,7 años. La clínica fue en todos los casos de tumoración parotídea de entre 1 y $3 \mathrm{~cm}$ de diámetro, indolora de consistencia dura y móvil (Fig. 1).

Se realizó sistemáticamente Punción Aspiración con Aguja Fina (PAAF) siendo los resultados sugestivos de adenoma pleomorfo en dos de los casos y adenoma monomorfo en los otros 2 casos.

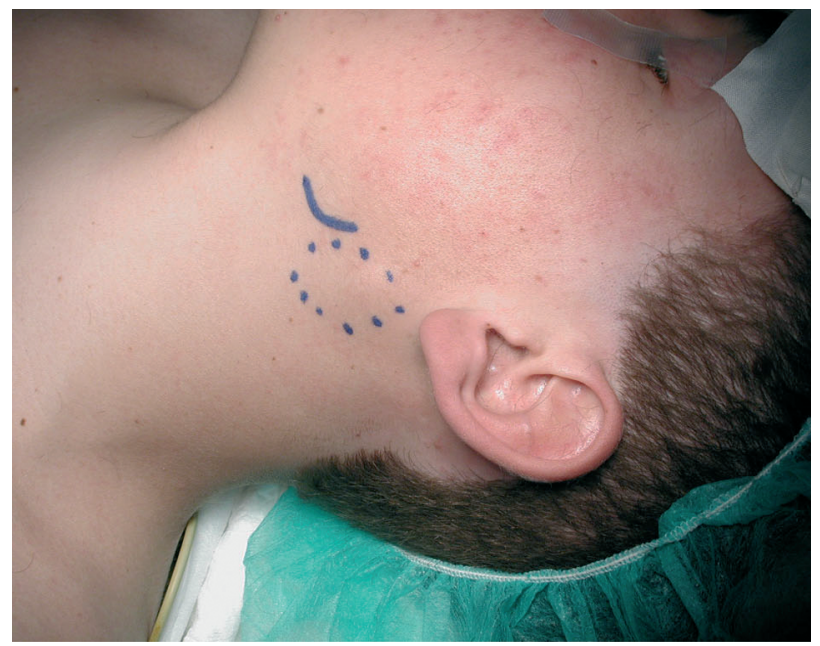

Introduction

The basal cell adenoma $(B C A)$ is a benign neoplasm with a uniform, monomorphous histologic appearance that is dominated by basaloid cells but that does not have the myxochondroid component of mixed tumors. They account for $2 \%$ of all primary salivary gland tumors and they are normally located in the parotid gland and in the minor salivary glands of the upper lip. ${ }^{1}$ There has been much controversy about the terminology and the spectrum of tumors that belong to this group following their description by Kleinsasser and Klein in 1967.2 In the monograph of the different histological types of salivary gland tumors by the World Health Organization (WHO) in $1972^{3}$ there were two categories of adenoma: Pleomorphic and monomorphic. Within monomorphic adenomas there were Warthin's tumors, Oncocytoma and Other Types, with no clear definition of the latter, meaning that various pathologists used the term monomorphic as a diagnostic entity. In a more recent revision of the histologic classifications of salivary gland tumors published by the WHO at the end of 1991, the term monomorphic is not used as a diagnostic category and variants are included of the specific types of adenoma, separated by their different morphologic features, and which included basal cell adenoma. ${ }^{2,4}$

\section{Clinical cases}

We present four cases diagnosed as basal cell adenoma during 2000-2003, in a series of 92 parotidectomies performed at the University Hospital of Son Dureta during this time period.

The patients consisted of 2 men and 2 women between the ages of 17 and 72 with a mean age of 43.7. The clinical was in all cases of a tumor-like mass of the parotid mea- 
La exploración radiológica mediante TC (Tomografía Computarizada) y/o RM (Resonancia Magnética) mostró en todos los casos una tumoración única, bien definida, de tamaño variable, de consistencia homogénea salvo en uno de los casos que presentó imágenes compatibles con sangrado postpunción (Fig. 2).

Se realizó parotidectomía superficial conservadora en todos los casos, utilizando la incisión modificada de Appiani, ${ }^{5}$ con levantamiento de colgajo de SMAS (Fig. 1).

Para el estudio histológico convencional se realizó fijación en formaldehído al 4\%, inclusión en parafina y tinción con hematoxilina-eosina.

Se diagnosticaron dos adenomas monomorfos de células basales subtipo membranoso, uno subtipo sólido y otro trabecular. Dentro de los adenomas de tipo membranoso uno era multinodular, en el resto de casos se trató de un nódulo único (Figs. 3-7).

Todos los pacientes fueron dados de alta dos días tras la intervención quirúrgica.

Un paciente presentó, como complicación postoperatoria inmediata, un hematoma local que se drenó y evolucionó favorablemente.

No hubo ningún caso de parálisis facial. Uno de los casos presentó una leve paresia de la rama marginal del nervio facial que había desaparecido a los 3 meses.

No ha habido ningún caso de recidiva local o de malignización, hasta el momento actual.

En los casos de adenoma de células basales membranosos, se realizó un despistaje de posibles lesiones cutáneas asociadas, que resultó negativo.
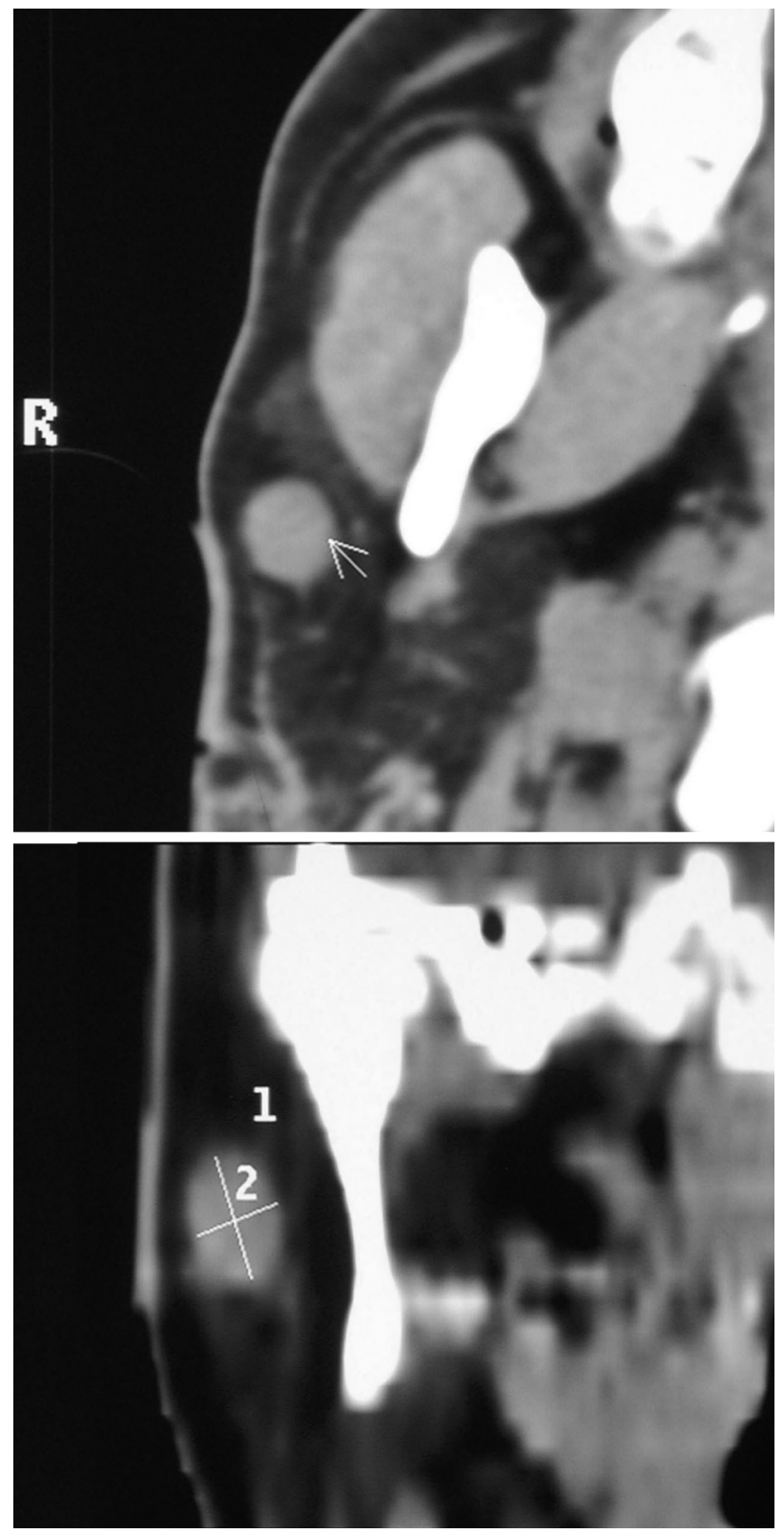

Figura 2. TC cervical. Serie axial con cortes de 3 mm. Lesión nodular de $1 \mathrm{~cm}$ a nivel de lóbulo superficial de parótida izquierda, bien delimitada e hiperdensa.

Figure 2. CT cervical scan. Axial series with $3 \mathrm{~mm}$ slices. Nodular lesion measuring $1 \mathrm{~cm}$ at the level of the superficial lobe of the left parotid that is well-defined and hyperdense. suring between 1 and $3 \mathrm{~cm}$ in diameter that was not painful and which was hard and movable (Fig. 1).

Fine needle aspiration (FNA) puncture was systematically carried out and the results were suggestive of pleomorphic adenoma in two cases and monomorphic adenoma in the other two cases.

The radiologic tests using $C T$ (computed tomography) scans and/or NMR (Nuclear Magnetic Resonance) showed in all cases a single tumorlike mass, that was welldefined, variable in size, with a homogenous consistency, except in one case in which images compatible with postpuncture bleeding could be seen (Fig. 2).

A conservative superficial parotidectomy was carried out in all cases, using a modified Appianis incision, with harvesting of a SMAS flap (Fig. 1.)

For the conventional histologic examination formaldehyde fixation was carried out at $4 \%$ with paraffin embedding and hematoxylin-eosin staining.

Two basal cell monomorphic adenomas were diagnosed of the membranous subtype. One was of the solid subtype and the other trabecular. Within the membranous type one was multinodular, and the remainder were uninodular (Figs. 3-7).

\section{Discusión}

Los adenomas de células basales constituyen aproximadamente el $2 \%$ de todos los tumores primarios de las glándulas salivares, según el registro de tumores de glándulas salivares de la AFIP. ${ }^{1}$ Atendiendo a su morfología pueden ser divididos en cuatro subtipos: sólido, trabecular, tubular y membranoso. ${ }^{4}$

La media de edad de los pacientes es de unos 58 años, con un pequeño pico de incidencia en la década de los 70. Predomina en
All the patients were discharged two days after surgery. One patient, who experienced a complication during the immediate post-operative period, developed a local hematoma that was drained and the evolution was favorable.

There were no cases of facial paralysis. One of the cases developed slight paresis of the marginal branch of the facial nerve that disappeared three months later.

To date there have been no cases of local relapse or of malignant transformation. 
mujeres 2:1, aunque el subtipo membranoso tiene una distribución semejante en ambos sexos.

Su localización más frecuente es la glándula parótida, en el $74 \%$ de los casos aproximadamente, seguida de las glándulas salivares accesorias del labio superior, en el 7,5\%, siendo esta la localización intraoral más frecuente; el resto se distribuyen entre las glándulas salivares accesorias de la mucosa bucal, la glándula submaxilar, las glándulas salivares palatinas, otras localizaciones orales y el cuello.

Existe una similitud histológica notable entre los tumores ecrinos dermales (cilindroma) y los adenomas de células basales, y cierta diátesis entre estos tumores y los adenomas de células basales parotídeos. Muchos de los adenomas asociados con tumores cutáneos son cilindromas dermales, por esto y por la semejanza histológica entre ambos tumores, Batsakis y Brannon, 6 denominan a los tumores parotídeos, análogos dermales, aunque Headington y cols. ${ }^{7}$, que fueron los primeros en describir la asociación entre ambos tipos de tumores, usan el término adenoma de células basales tipo membranoso.

El hallazgo clínico más frecuente en estos adenomas es el de una tumoración, que suele ser un nódulo único, bien definido, salvo en el subtipo membranoso que puede ser multifocal. Su consistencia es firme, aunque en ocasiones se trata de un tumor quístico, más compresible y son móviles a la palpación salvo que se localicen en el paladar duro.

En cuanto a sus características macroscópicas, con la excepción de algunos tumores de tipo membranoso que son multinodulares o multifocales, se trata de tumores únicos, bien delimitados y en la mayoría de los casos menores de 3 $\mathrm{cm}$ de diámetro en el momento de la excisión, con un rango entre 1,2 y $8 \mathrm{~cm}$. Dentro de la parótida, se sitúan con mayor frecuencia en la porción superficial del lóbulo lateral, y poseen habitualmente una cápsula bien definida. Los adenomas monomorfos intraorales aunque son tumores bien definidos, no suelen ser encapsulados.

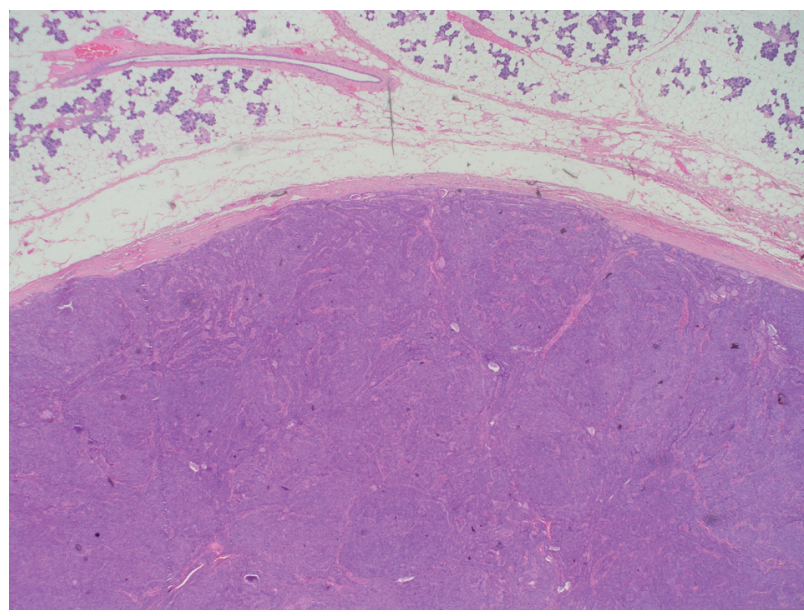

Figura 3. Tumoración monomorfa encapsulada (HE x 20). Figure 3. Encapsulated monomorphic tumor-like mass, (HE $\times 20)$.

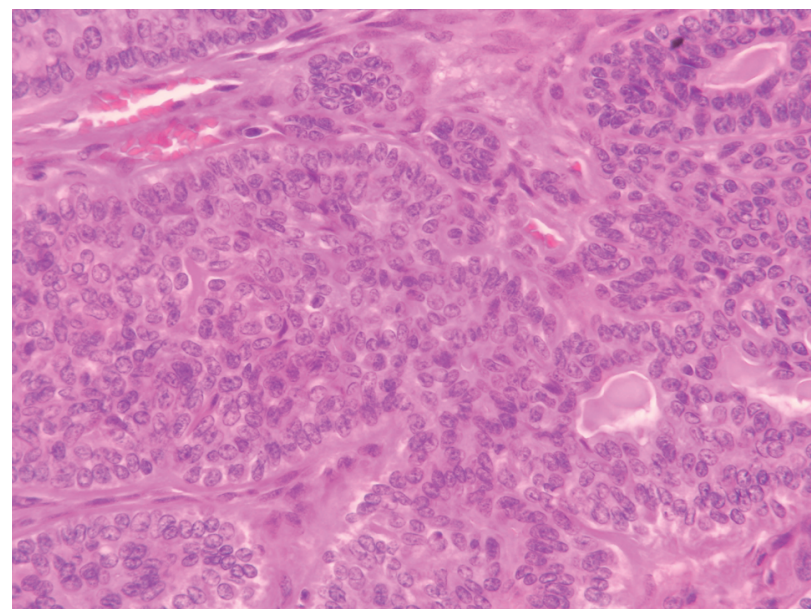

Figura 4. Proliferación de células basaliodes con pequeñas luces ductales (HE X 200).

Figure 4. Basaloid cell proliferation with small ductal lumina, (HEX 200).

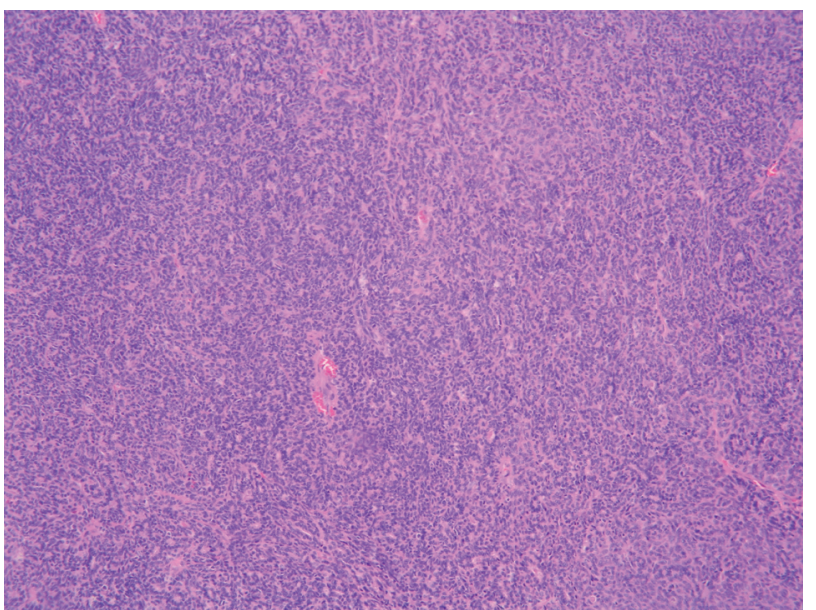

Figura 5. Patrón de crecimiento sólido, (HE x 40). Figure 5. Solid growth pattern, (HE x 40).
In the membranous basal cell adenoma cases, screening was carried out of possible associated cutaneous lesions, that proved negative.

\section{Discussion}

Basal cell adenomas account for approximately $2 \%$ of all primary tumors of the salivary glands, according to the AFIP register of salivary gland tumors. ${ }^{1}$ On the basis of their morphologic pattern they can be divided into four subtypes: solid, trabecular, tubular and membranous. ${ }^{4}$

The mean age of the patients is 58 , with a small peak in incidence in the 70s decade. It is more predominant in females with a 2:1 ratio, although the membranous subtype has a similar distribution in both sexes.

The basal cell adenoma is most commonly located in the parotid gland, in $74 \%$ of cases approximately, followed by the salivary glands of the upper lip, with this intraoral location being the most common in $7.5 \%$. The remainder is distributed amongst the accessory salivary glands of the buccal mucosa, the submaxillary gland, the salivary glands of the palate, and other oral locations and the neck.

There is a remarkable histological similitude between eccrine dermal tumors (cylindromas) and basal cell adenomas, and there is certain diathesis with these tumors and basal cell adenoma of the parotid gland. Many of the adenomas associated with cutaneous tumors are dermal cylindromas. As a result of this and the histologic resemblance between 
El color de la superficie es habitualmente uniforme y suelen tener una textura homogénea. Durante años tras la descripción inicial de estos tumores por Kleinsasser y Klein, ${ }^{2}$ se interpretó el término monomorfo, como isomorfismo y ausencia de diferenciación mioepitelial. Estudios más recientes, incluyendo microscopía electrónica e inmunohistoquímica, revelan que la diferenciación basal, ductal o mioepitelial se produce en diferentes grados en los adenomas de células basales como en otro tipo de tumores de las glándulas salivares. El carácter monomorfo de estos tumores es el resultado de un patrón de crecimiento uniforme en mayor o menor grado con ausencia del tejido mixocondroide que caracteriza a los tumores mixtos. En contraste con otro tipo de adenomas también llamados monomorfos, en el adenoma de células basales predominan las células basaliodes. Es conveniente usar el término basaliode en términos de microscopía óptica porque evita la necesidad de determinar si las células son basales, mioepiteliales o ductales, lo cual en ocasiones resulta dificultoso en estos tumores sin estudios añadidos con microscopio electrónico o inmunohistoquímica.

Como hemos mencionado anteriormente, los adenomas de células basales pueden dividirse en cuatro subtipos en base a su morfología histológica: sólido, trabecular, tubular y membranoso. A pesar de estos diferentes patrones morfológicos, poseen características histológicas de base que facilitan su diagnóstico.

En cuanto a los distintos subtipos morfológicos, un tumor puede presentar uno o más de estos patrones de crecimiento pero la mayoría de los adenomas de células basales se puede tipificar en una de estas categorías en función del patrón que predomina. Excepto para el tipo membranoso, la identificación de estos subtipos tiene un propósito meramente descriptivo y no implica un comportamiento biológico diferente.

El subtipo más frecuente es el sólido, que se compone de células epiteliales neoplásicas dispuestas en islas o cordones con un patrón lobular o redondea-

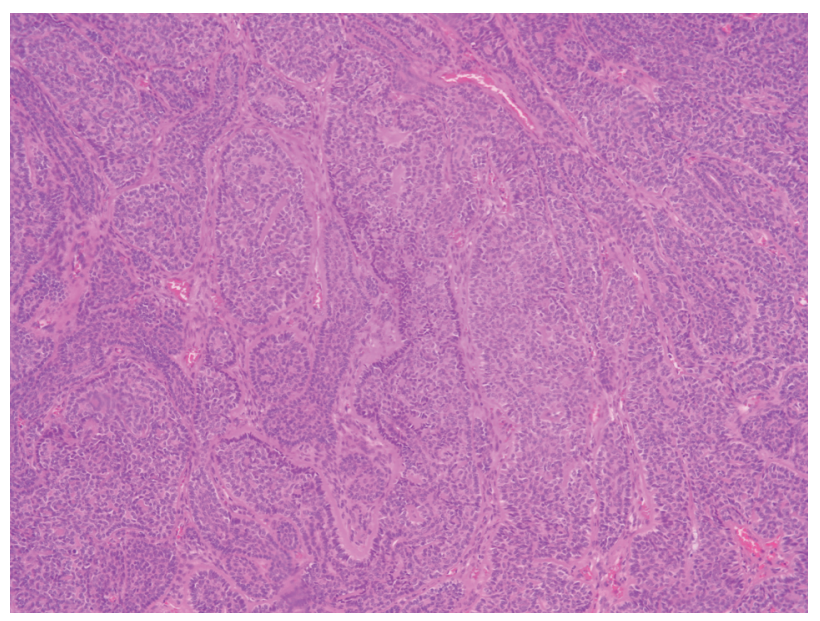

Figura 6. Patrón de crecimiento sólido y trabecular, (HE x 100). Figure 6. Solid and trabecular growth pattern, (HE x 100).
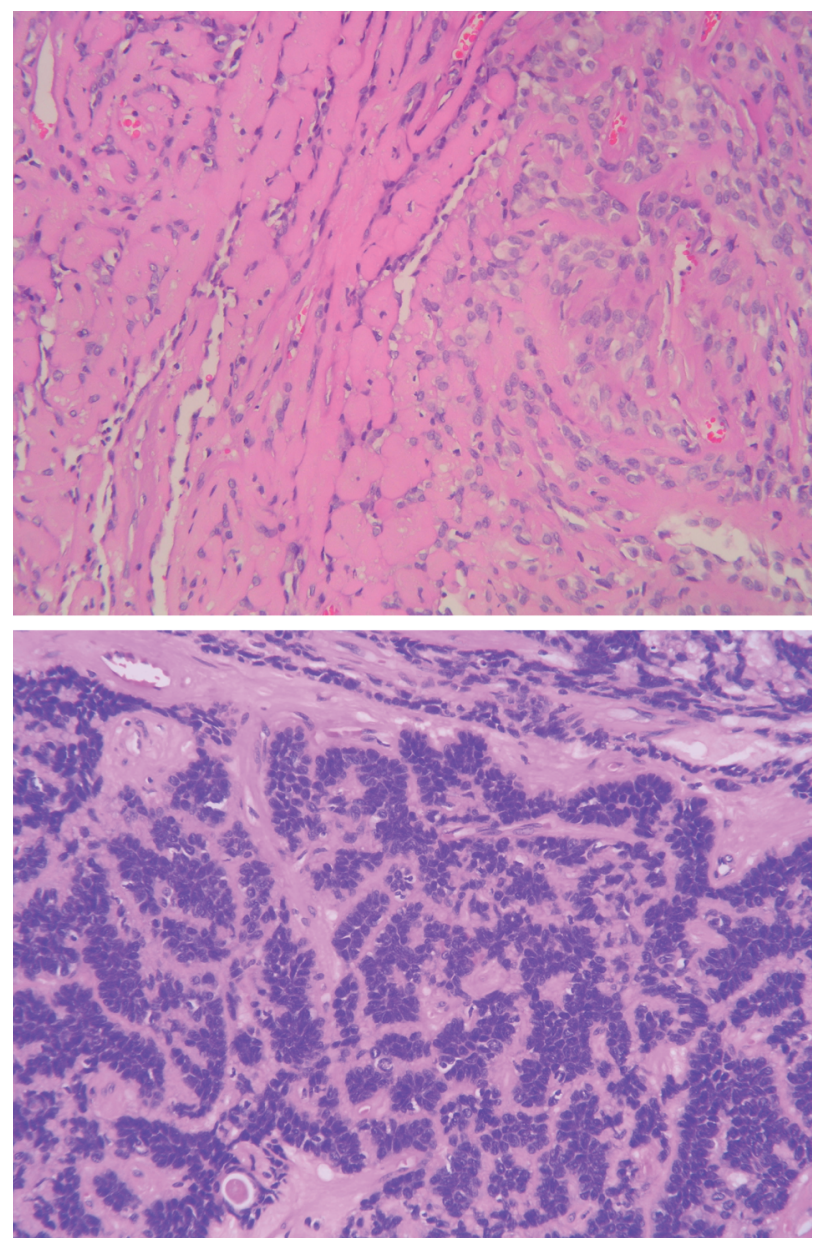

Figura 7. Patrón de crecimiento membranoso. Abajo: Nidos de células basalioides separados por membranas hialinas tipo lamina basal, (HE x 100). Arriba: Material membranáceo hialino tipo lámina basal (HE x 400).

Figure 7. Membranous growth pattern. Down: Basaloid cell nests separated by hyaline membranes basal type sheets, (HE x 100). Above: Hyaline membranous material of a basal[cell] sheet type, (HE $\times$ 400). both tumor-like masses, Batsakis and Brannon ${ }^{6}$ called parotid tumors, dermal analogue tumors, although Headington and cols., ${ }^{7}$ who were the first to describe the association between both types of tumors, coined the term membranous-type basal cell adenoma.

The most common clinical finding in these adenomas is of a tumor-like mass that tends to be uninodular and well-defined, except in the membranous subtype where it can be multifocal. It has a firm consistency, although on occasions it can be a cystic tumor, softer on compression and moving to palpation except when located in the soft palate. With regard to their macroscopic features, with the exception of some membranous type tumors that are multinodular or multifocal, these are solitary tumors that have well-defined borders. In most cases they measure less that $3 \mathrm{~cm}$ in diameter on excision, they can range between 1.2 and $8 \mathrm{~cm}$. The most common location within the parotid gland is in the superficial portion of the lateral lobe, and they usually have a well-defined capsule. Intraoral monomorphic adenomas, although being welldefined tumors, do not tend to be encapsulated.

The surface color is usually uniform and it tends to have a homogenous texture. Many years ago, following the initial description of these tumors by Kleinsasser and Klein, ${ }^{2}$ the term monomorphic was interpreted as isomorphic with the absence of myoepithelial differentiation. More recent studies, including electron microscopy and 
do que muestran una capa de células periféricas hipercromáticas dispuestas en empalizada. El estroma que separa estos agregados epiteliales está constituido por tejido conectivo denso.

El subtipo trabecular se caracteriza por una red de bandas estrechas y entrelazadas de células basaliodes. El estroma en estos tumores está formado por tejido conectivo laxo.

El subtipo tubular es el menos frecuente y se caracteriza por la diferenciación ductal. La luz tubular aparece bordeada por células ductales cuboidales, y en la perifería se observan varias capas de células basaliodes. Estos agregados epiteliales se encuentran muy próximos entre si, con muy poca cantidad de estroma alrededor.

Por último el subtipo membranoso se asemeja a la variante sólida del adenoma de células basales con la excepción de que es con frecuencia multinodular y es encapsulado en aproximadamente la mitad de los casos. Su rasgo distintivo es la gruesa capa eosinofílica, hialina que forma anchas bandas en la periferia de los islotes de células basaliodes. Este material hialino, PAS positivo corresponde como ha mostrado la microscopía electrónica a una duplicación de la membrana basal. Además pequeños acúmulos de material hialino, coalescentes, a menudo están presentes en el espacio intercelular en los agregados tumorales. El estroma se compone habitualmente de tejido conectivo denso.

Además de las características clínicas comunes al adenoma de células basales, como son la localización más frecuente en la parótida y el tratarse de masas asintomáticas, móviles, este subtipo tumoral presenta dos características clínicas propias. Una de ellas es su asociación con el cilindroma dermal, tricoepitelioma o espiradenoma ecrino del cuero cabelludo. Aproximadamente en un tercio de los casos publicados se describen cilindromas dermales sincrónicos. Las localizaciones incluyen cuero cabelludo, pezones, espal$\mathrm{da}$, muslos, piernas y escroto. Pueden localizarse en cualquier parte excepto en las palmas, plantas y axilas. Habitualmente los tumores son múltiples, más de 10 en número. Es conveniente por tanto, realizar un cribaje de lesiones cutáneas en cuero cabelludo y otras localizaciones, en todos los pacientes con adenoma de células basales membranoso parotídeo. De la misma manera, revisar la glándula parótida en los pacientes que presenten cilindromas dermales en cuero cabelludo. Otra característica clínica del adenoma membranoso de células basales es su tendencia hereditaria. Esta tendencia parece más evidente en pacientes que muestran tumores múltiples que en aquellos que presentan formas solitarias. Por tanto en pacientes con múltiples tumores sincrónicos se aconseja un estudio familiar. ${ }^{8}$

Las principales entidades que se deben diferenciar del adenoma de células basales son el tumor mixto, el carcinoma adenoide quístico y el adenocarcinoma de células basales.

El adenoma canalicular, entidad distinta del adenoma de células basales, se localiza más frecuentemente en el labio superior e histológicamente se debe diferenciar sobre todo del subtipo trabecular.

El tejido condromixoide del tumor mixto lo distingue del adenoma de células basales, si bien algunos tumores mixtos son muy celulares y poseen cantidades mínimas de tejido mixocondroide. Aunque el uso de la inmunohistoquímica para distinguir un tipo de tumor de glándula salivar de otro está cargado de errores, la inmu- immunohistochemistry have shown that basal, ductal or myoepithelial differentiation is produced to different degrees in basal cell adenomas, as occurs in other types of salivary gland tumors. The monomorphic character of these tumors is the result of a growth pattern that is to a greater or lesser degree uniform, and that does not have the myxochodroid tissue that is characteristic of mixed tumors. In contrast with other types of adenoma also called monomorphic, the basal cell adenoma is dominated by basaloid cells. The term basaloid should be used for optic microscopic terms as it avoids the necessity of determining whether the cells are basal, myoepithelial or ductal, as this is on occasions difficult with these tumors without further study with electron microscopy or immunohistochemistry.

As we have mentioned previously, basal cell adenomas can be divided into four subtypes based on their histological morphology: solid, trabecular, tubular and membranous. Despite these different morphologic patterns, they have basic histologic features that help in their diagnosis.

With regard to the different morphologic subtypes, a tumor can have one or more of these growth patterns, but most basal cell adenomas can be classified into one of these categories based on the predominating pattern. With the exception of the membranous type, the identification of these subtypes is for merely descriptive purposes and it does not imply different biological behavior.

The most common subtype is the solid variant, which is made up of neoplastic epithelial cells set out in islands or strands with a dominant lobular or rounded pattern, and it has a layer of hyperchromatic peripheral cells set out in a palisade pattern. The stroma that separates these additional epithelial cells is made up of dense connective tissue.

A net of tight interwoven bands of basaloid cells characterizes the trabecular subtype. The stroma in these tumors is formed by loose connective tissue.

The tubular subtype is less common and it is characterized by ductal differentiation. The tubular lumina appear to have a border of cuboidal ductal cells, and at the periphery several layers of basaloid cells can be observed. The epithelial aggregates are closely packed, and they have very little stroma around them.

Lastly, the membranous subtype is similar to the solid variant of basal cell adenoma except that it is frequently multinodular and it is encapsulated in approximately half the cases. Its distinctive feature is a thick eosinophilic hyaline layer that forms a wide rim around the edge of the islands of basaloid cells. This hyaline material, which is PAS-positive, corresponds as demonstrated by electron microscopy, to a duplicated basal membrane. In addition, small accumulations of hyaline coalescent material are often present in the intracellular space of tumor aggregates. The stroma is usually composed of dense connective tissue.

In addition to the common clinical features of basal cell adenomas, such as their most common location being in the parotid and their being movable asymptomatic mass- 
noreactividad positiva para la proteina glial fibrilar ácida (GFAP) habla a favor del tumor mixto.

En cuanto al carcinoma adenoide quístico, el patrón citomorfológico cribiforme común en este tipo de tumores es raro en el adenoma de células basales y cuando aparece se acompaña de patrones de crecimiento sólidos o trabeculares típicos. La infiltración e invasión perineural ayuda a distinguir el carcinoma adenoide quístico del adenoma de células basales.

El adenocarcinoma de células basales es la variante maligna del adenoma de células basales y su distinción del adenoma de células basales se basa en las características de crecimiento y en la mayor agresividad en su comportamiento. Estas características de crecimiento incluyen invasión del parénquima parotídeo y tejidos adyacentes como grasa, músculo, piel y hueso, así como invasión vascular y perineural. Un recuento de mitosis mayor de 3-10 por campo es altamente sugestivo de malignidad aunque un número menor de las mismas no garantiza que el tumor sea benigno. El pronóstico es bueno.

Excepto para el tipo membranoso el índice de recurrencia es muy bajo, casi inexistente cuando se trata de forma conservadora pero adecuada, lo cual significa una parotidectomia superficial, una submaxilectomia, una exéresis de la glándula sublingual o una excisión con márgenes adecuados en las localizaciones intraorales.

En contraste con los otros subtipos de adenomas de células basales, el subtipo membranoso, tiene un índice de recurrencia del $25 \%$ aproximadamente, ${ }^{6}$ probablemente por ser más frecuentemente multifocal y no encapsulado, por este motivo algunos autores aconsejan parotidectomia total ${ }^{7}$ en esta variante, debido a que atribuyen este índice de recurrencias a la resección incompleta por su multifocalidad. Sin embargo la metodología de estudio en estos pacientes no permite en la mayoría de los casos el conocimiento del subtipo histológico previamente a la cirugía. Por este motivo nosotros realizamos parotidectomía total solo en aquellos casos en los que radiologicamente se observan multiples nódulos.

Se ha descrito la transformación maligna de estos tumores, de hecho Batsakis, ${ }^{6}$ habla de un índice del $28 \%$ en los adenomas membranosos y cerca del $4 \%$ para otros tipos de adenomas de células basales. Debido a estos factores se aconseja un seguimiento estrecho de los adenomas membranosos de células basales.

Es extremadamente difícil establecer dentro del adenocarcinoma de células basales cuales parten de un lesión benigna preexistente y cuales han aparecido de novo.

\section{Conclusiones}

El adenoma de células basales se define como categoría diagnóstica en el monográfico de tumores de glándulas salivares de la OMS publicado a finales de 1991. Se trata de una neoplasia epitelial benigna de apariencia histológica uniforme y monomorfa, en la que predominan las células basaliodes sin el componente mixocondroide del tumor mixto.

Se puede dividir en cuatro subtipos atendiendo a su morfología: sólido, tubular, trabecular y membranoso, con una finalidad meramente descriptiva salvo en el subtipo membranoso por su es, this tumor-like subtype has two clinical features of its own. One is its association with the dermal cylindroma, the trichoepithelioma or the eccrine spiradenoma of the scalp. Approximately a third of the cases published describe synchronous dermal cylindromas. These are also located in the scalp, nipples, back, thighs, legs and scrotum. They can be located in any part except for the palms, the soles and the axillae. There are commonly many tumors - more than ten in number. In patients with membranous basal cell adenoma of the parotid the screening of any skin lesions in the scalp or in any other location is therefore advisable. Similarly, the parotid gland should be checked in those patients that present with dermal cylindroma of the scalp. Other clinical features of the membranous basal cell adenoma is its tendency to be hereditary. This tendency tends to more evident in patients with multiple tumors than those that present with a solitary form. Therefore, in patients with multiple synchronous tumors a family investigation is advisable. $^{8}$

The principal entities that should be distinguished from the basal cell adenoma are the mixed tumor, the adenoid cystic carcinoma and the basal cell adenocarcinoma. The most common location for the canalicular adenoma, which is different to the basal cell adenoma, is the upper lip and it should be differentiated histologically from the trabecular subtype in particular.

The chondromyxoide tissue of the mixed tumor distinguishes it from the basal cell adenoma, although some mixed tumors are very cellular and they possess minimal quantities of myxochondroid tissue. Although the use of immunohistochemistry for distinguishing one type of salivary gland from another is full of errors, positive immunoreactivity for the glial fibrillary acid protein (GFAP) speaks in favor of the mixed tumor.

With regard to the adenoid cystic carcinoma, the cytomorphologically common cribiform pattern in this type of tumor is rare in the basal cell adenoma, and when it does appear it is accompanied by solid growth patterns or by typical trabeculae. Infiltration and perineural invasion helps to distinguish the adenoid cystic carcinoma from the basal cell adenoma.

The basal cell adenocarcinoma is a malignant variant of the basal cell adenoma and it can be distinguished from the basal cell adenoma on the basis of its characteristic growth and its more aggressive behavior. These growth characteristics include invasion into the parotid gland parenchyma and the adjacent tissues such as fat, muscle and bone as well as vascular and perineural invasion. A mitosis count that is 3-10 higher per field is highly suggestive of malignancy although a smaller number does not guarantee that the tumor is benign. The prognosis is good.

With the exception of the membranous type, the recurrence rate is very low, and even inexistent when conservative treatment is given adequately. This signifies a superficial parotidectomy, a submaxillectomy, an excision of the 
mayor tendencia a la multifocalidad y a la recidiva, su ocasional transformación maligna así como por su asociación en un tercio de los casos aproximadamente a los tumores ecrinos dermales. Esto conlleva un seguimiento más estrecho, un despistaje de lesiones cutáneas e incluso la realización de parotidectomia total en caso de multifocalidad.

\section{Bibliografía}

1. Kratochvil FJ, Auclair PL, Ellis GL. Clinical Features of 160 cases of basal cell adenoma and 121 cases of canalicular adenoma. Oral Surg Oral Med Oral Pathol 1990;70:605.

2. Kleinsasser O, Klein HJ. Basalzelladenome der Speicheldrusen. Arch Klin Exp Ohren Nasen Kehlkopfheilkd 1967;189:302-16.

3. Trackay AC, Sobin LH. Histological typing of salivary gland tumours. En: World Health Organization. International histological classification of tumores. Geneva: The Organization, 1972.

4. Seifert G, Sobin LH. Histological classification of salivary gland tumours. En: World Health Organization. International histological classification of tumors. Berlin: Springer-Verlag, 1991.

5. Appiani E, Dlfino MC. Plastic incisions for facial and neck tumors. Ann Plast Surg 1984;13:335-52.

6. Batsakis JG, Brannon RB. Dermal analogue tumors of major salivary glands. J Laryngol Otol 1981;95:155-64.

7. Headington JT, Batsakis JG, Beals TF, y cols. Membranous basal cell adenoma of the parotid gland, dermal cylindromas, and trichoepitheliomas: comparative histochemistry and ultraestructure. Cancer 1977;39:2460-9.

8. Yu GY, Ubmüller J, Donath K. Membranous basal cell adenoma of the major salivary gland: a clinicopathologic study of 12 cases. Acta Otolaryngol (Stockh) 1998; 118:588-93.

9. Ellis GL, Auclair PL. Tumors of the salivary glands. Atlas of Tumor Pathology. Whashington, DC, Armed Forces Institute of Pathology, 1996; p.p. 80-94.

10. Ellis GL, Auclair PL, Gnepp DR. Surgical Pathology of the Salivary Glands. Philadelphia, W.B. Saunders Company 1991; p.p. 202-24. sublingual gland or an excision with adequate margins for intraoral locations.

Unlike other basal cell adenoma subtypes, the membranous subtype has a recurrence rate of approximately $25 \%, 6$ probably as a result of it being more commonly multifocal and not encapsulated. For this reason some authors advise a total parotidectomy ${ }^{7}$ with this variant, due to the rate of recurrence being attributed to incomplete resection as a result of it being multifocal. Nevertheless the study method of these patients in most cases does not allow knowing the histological subtype before the surgery. For this reason we only carry out a total parotidectomy in those cases in which multiple nodes have been observed radiologically.

The malignant transformation of these tumors has been described, and Batsakis ${ }^{6}$ in fact refers to a rate of $28 \%$ of membranous adenomas and $4 \%$ for other types of basal cell adenomas. Due to these factors a close follow-up is advised of membranous basal cell adenomas.

Establishing within basal cell adenocarcinomas which ones arise from a preexisting benign lesion and which ones are new is extremely difficult to establish.

\section{Conclusion}

The basal cell adenoma is defined as a diagnostic category within the WHO's monograph of salivary glands published at the end of 1991. It is a benign epithelial neoplasm that histologically has a uniform and monomorphous appearance. It is predominated by basaloid cells and it does not have the myxochondroid component of the mixed tumor.

It can be divided into four subtypes for merely descriptive purposes based on its morphology: solid, tubular, trabecular and membranous. The exception is the membranous subtype as a result of its greater tendency to be multifocal and recur, and of its occasional malignant transformation as well as its association in approximately a third of the cases with dermal eccrine tumors. It requires a close follow-up, cutaneous lesions should be screened, and a total parotidectomy may even have to be performed in the event of it being multifocal. 